\title{
Education Research: Simulation training for neurology residents on acquiring tPA consent
}

\section{An educational initiative}

Sara K. Rostanski, MD, Arielle M. Kurzweil, MD, Sondra Zabar, MD, Laura J. Balcer, MD, Koto Ishida, MD, Steven L. Galetta, MD, and Ariane Lewis, MD

Neurology ${ }^{\circledR}$ 2018;91:e2276-e2279. doi:10.1212/WNL.0000000000006651

The time-sensitive nature of acute ischemic stroke diagnosis and treatment with IV tissue plasminogen activator ( $\mathrm{tPA}$ ) presents a unique set of challenges for obtaining informed consent. Despite guideline recommendations that informed consent is indicated for thrombolysis, ${ }^{1}$ there is no accepted standardized consent process for thrombolytic administration and wide variability has been reported. ${ }^{2}$ Refusal of IV-tPA based on incorrect or incomplete understanding of its risks and benefits has the potential to affect morbidity after ischemic stroke, particularly for minority race/ethnic groups. ${ }^{3}$

Although decisions about IV-tPA administration are usually made after consultation with a stroke fellow/attending at teaching hospitals, the process of obtaining IV-tPA consent is often assigned to neurology residents. Despite this, there is no standardized competency on IV-tPA consent and neurology residents are rarely provided feedback about obtaining consent. As a result, this process can be challenging for trainees. The existence of deficiencies in resident training on the general process of obtaining informed consent has previously been acknowledged, ${ }^{4}$ but little mention is made in the literature on the specific process of acquiring consent for IV-tPA, which is unique given critical time sensitivity and the serious risks associated with both not giving and giving IV-tPA. Simulation-based education has the potential to address this gap in neurology education. ${ }^{5}$ We developed a simulation session in which first year neurology residents discuss the risks and benefits of IV-tPA with a standardized patient (SP) during an observed standardized clinical encounter (OSCE). In this article, we discuss (1) the residents' perspective on how they learned about IV-tPA consent before the simulation, (2) the residents' feedback on simulation as an educational strategy for IV-tPA consent, and (3) the SP's assessment of resident performance during the simulation.

\section{Methods}

Before the 2017-2018 academic year, residents did not receive dedicated didactics on acquiring IV-tPA consent. However, at the beginning of the N1 year, all residents attended a lecture on running stroke codes and participated in a mock code, during which the general risks and benefits of IV-tPA were discussed. They also received cards with a visual display of IV-tPA risks and benefits ${ }^{6}$ and a sample script for obtaining consent. In addition, they attended a lecture on IV-tPA trials, which contained data that are useful in consent discussions.

In 2017, in conjunction with the New York University School of Medicine Simulation Center (NYSIM), we designed a 4-station OSCE for N1 residents to provide training in core communication skills including acquiring consent for IV-tPA. An SP was trained for 4 hours by a NYSIM SP trainer and vascular neurology attending on their character profile and a checklist with communication and case specific items for them to evaluate the residents after the IV-tPA consent simulation. The residents were told through instructions on the door of the simulation room that (1) the patient developed left arm weakness and numbness 95 minutes prior to presentation to the emergency department and had an NIH Stroke Scale score of 10, (2) a CT

\author{
Correspondence \\ Dr. Rostanski \\ sr1560@nyumc.org
}


showed no acute pathology, and (3) they had discussed the case with a stroke fellow, and the decision was made to give IV-tPA. The residents' task was to explain the clinical assessment and the risks/benefits of IV-tPA to the patient. The OSCE script data are available from Dryad (appendix, doi. org/10.5061/dryad.qm23g80). The clinical encounter, which was observed by a vascular neurology attending through oneway glass, ended when the SP agreed to treatment or after 10 minutes. The encounter was followed by 5 minutes of feedback about the consent discussion from both the attending and the SP.
Prior to the OSCE, all neurology residents $(n=47)$ at our institution were surveyed on how they learned to perform IV-tPA consent and their comfort with the consent process (figure). After completion of the OSCE, first-year neurology residents were surveyed on how prepared they felt for the IV-tPA consent case, how useful it was, and how they would rate their performance on a Likert scale from 1 to 5 (worst to best). They were also asked to provide a free text response about how challenging the simulation was. The SP completed a checklist for each resident in which he or she recorded whether specific components of the

Figure Responses to survey questions about resident perceptions about IV tissue plasminogen activator (tPA) consent prior to the IV-tPA consent observed standardized clinical encounter

A. Which methods have you used to learn how to discuss the risks and benefits of IV-tPA with a patient/their family?

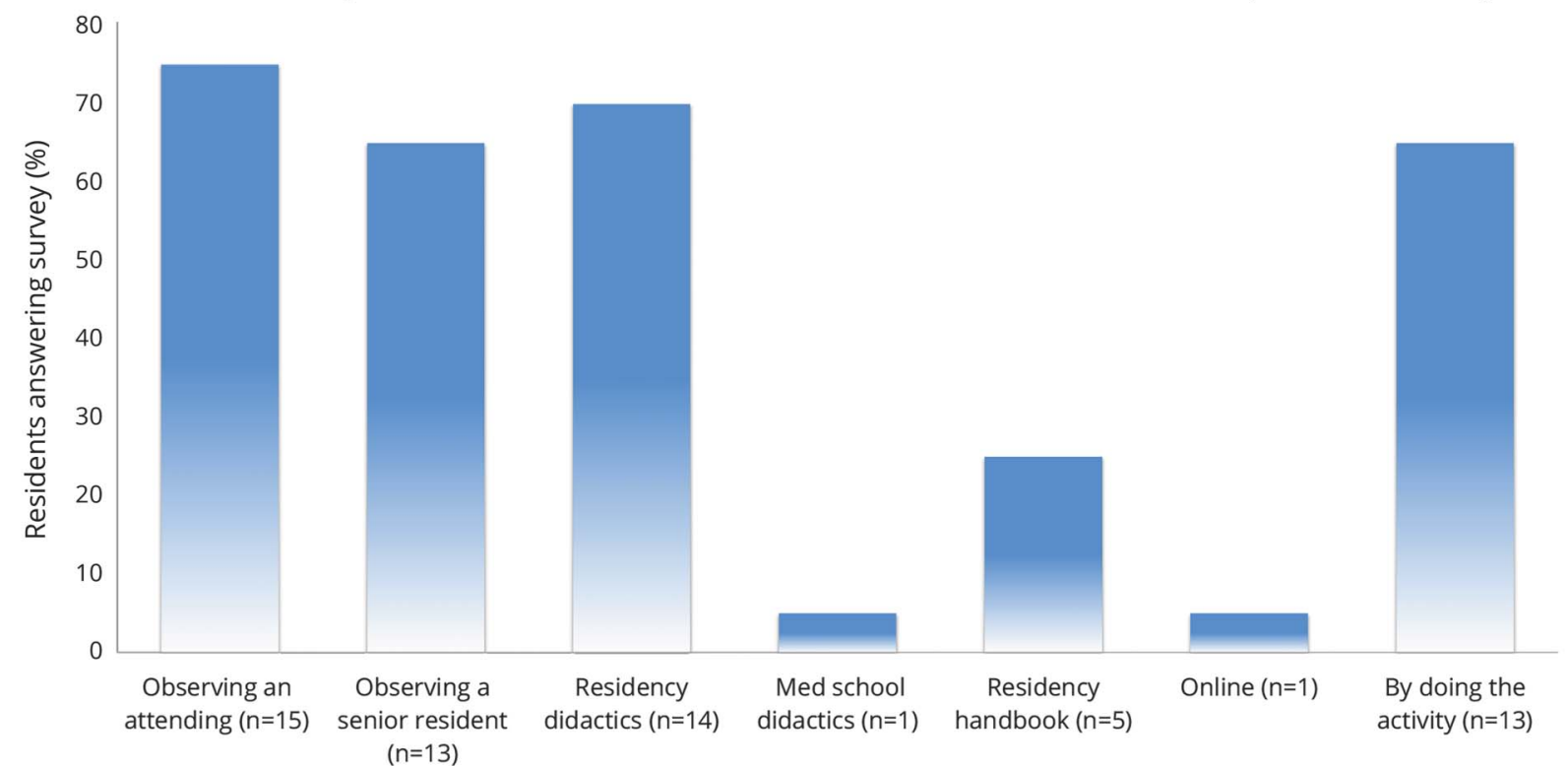

B. How often do you think that discussions about the risks/benefits of tPA lead to delays in TPA administration?

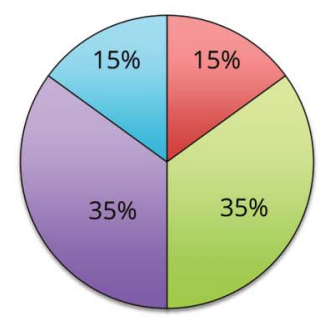

$\square$ Extremely often $(n=0)$ $\square$ Very often $(n=3)$ $\square$ Sometimes $(n=7)$ $\square$ Occasionally $(\mathrm{n}=7)$ $\square \operatorname{Never}(n=3)$

C. How comfortable do you feel discussing risks and benefits of IV-tPA with a patient/their family?

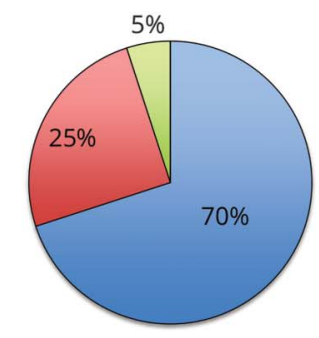

$\square$ Very comfortable $(n=14)$

$\square$ Somewhat comfortable $(n=5)$

$\square$ Somewhat uncomfortable $(n=1)$

$\square$ Very uncomfortable $(n=0)$

E. Has a neurology faculty member ever observed you discuss risks and benefits of IV-tPA with a patient/ their family?

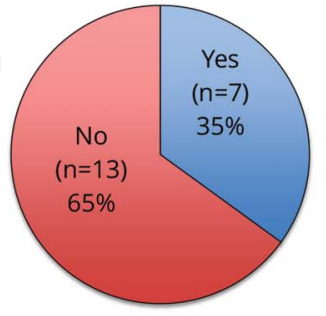

D. When discussing risks/benefits of IV-tPA with a patient/their family, how often do you think the person you are speaking to fully understands everything you say?

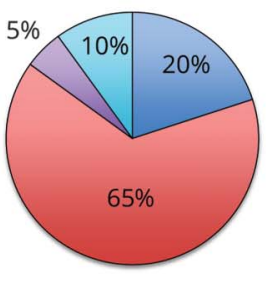

$$
\begin{aligned}
& \square \text { Always }(n=4) \\
& \square \text { Usually } \\
& (n=13) \\
& \square \text { Sometimes } \\
& (n=0) \\
& \square \text { Occasionally } \\
& (n=1) \\
& \square \text { N/A }(n=2)
\end{aligned}
$$

F. Has a neurology faculty member ever given you feedback on your performance discussing the risks and benefits of IV-tPA with a patient/ their family? 
consent process were not done, partly done, or well done (table).

\section{Results}

The pre-OSCE survey was completed by 20/47 residents in the NYU-Manhattan and NYU-Brooklyn adult neurology, child neurology, and neuropsychiatry residency programs ( $50 \%$ male; $30 \% \mathrm{~N} 1,25 \% \mathrm{~N} 2,45 \% \mathrm{~N} 3$ ). When asked to indicate all the methods by which they had learned how to discuss the risks and benefits of IV-tPA, the majority reported that they learned how to obtain consent through observation (75\% observation of an attending or fellow, 65\% observation of a senior resident), didactics (70\%), or simply by doing the activity (65\%). The figure includes responses to other preOSCE survey questions.

The IV-tPA consent case was completed by $17 / 18$ first-year neurology residents (41\% male; $76 \%$ adult neurology, $12 \%$ child neurology, $12 \%$ neuropsychiatry). The residents

Table Standardized patient checklist to assess resident performance during the IV tissue plasminogen activator (tPA) observed standardized clinical encounter (OSCE)

\begin{tabular}{|c|c|c|c|}
\hline Case-specific checklist items & $\begin{array}{l}\text { Not } \\
\text { done }\end{array}$ & $\begin{array}{l}\text { Partly } \\
\text { done }\end{array}$ & $\begin{array}{l}\text { Well } \\
\text { done }\end{array}$ \\
\hline $\begin{array}{l}\text { Conveyed clear assessment of } \\
\text { clinical impression that "you are } \\
\text { having a stroke" }\end{array}$ & $0(0)$ & $1(6)$ & $16(94)$ \\
\hline $\begin{array}{l}\text { Conveyed clear recommendation } \\
\text { for treatment with IV-tPA }\end{array}$ & $0(0)$ & $2(12)$ & $15(88)$ \\
\hline $\begin{array}{l}\text { Able to clearly explain the benefits } \\
\text { on 3-month disability with IV-tPA } \\
\text { treatment }^{\mathrm{a}}\end{array}$ & $14(88)$ & $2(13)$ & $0(0)$ \\
\hline $\begin{array}{l}\text { Able to clearly explain the risk of } \\
\text { brain hemorrhage with IV-tPA; } \\
\text { clearly conveyed that this occurs } \\
\text { in a minority of patients and that } \\
\text { only } 3 \% \text { are truly made worse by } \\
\text { hemorrhage }\end{array}$ & $1(6)$ & $13(77)$ & $3(17)$ \\
\hline $\begin{array}{l}\text { Able to maintain composure and } \\
\text { respond appropriately to concerns } \\
\text { about the recommendations for } \\
\text { IV-tPA }\end{array}$ & $0(0)$ & $2(12)$ & $15(88)$ \\
\hline $\begin{array}{l}\text { Made you feel like you had a full } \\
\text { understanding of the risks and } \\
\text { benefits of treatment with IV-tPA } \\
\text { for acute stroke }\end{array}$ & $0(0)$ & $12(71)$ & $5(29)$ \\
\hline $\begin{array}{l}\text { Provided appropriate next steps } \\
\text { (admission to stroke unit, close } \\
\text { monitoring for signs of bleeding } \\
\text { and blood pressure, } \\
\text { communicated doctor would be in } \\
\text { hospital all night) }\end{array}$ & $0(0)$ & $12(71)$ & $5(29)$ \\
\hline
\end{tabular}

Values are $\mathrm{n}(\%)$ of the 17 neurology residents who completed the OSCE. ${ }^{a} \mathrm{~N}=16$ as the standardized patient did not respond to this question for 1 resident. reported they felt only somewhat prepared for the OSCE ( mean Likert score $=3.4 / 5$ ) and believed they performed fairly well (mean Likert score $=3.5 / 5$ ), but they found the IVtPA case to be very helpful (mean Likert score $=4.8 / 5$ ). In response to an open-ended question on the most challenging aspects of the case, many noted difficulties discussing risks and benefits of IV-tPA, and having the discussion rapidly. For example, one resident reported that "explaining benefits in the most compelling and understandable way while also communicating urgency" was a challenge. For many residents, developing the physician-patient relationship in a timesensitive situation was also challenging. For example, "building rapport quickly" and "balancing urgency of therapy with empathizing with the patient" were listed as difficulties encountered during the OSCE.

The aggregate results of the SP checklist for all residents are shown in the table. Nearly every resident conveyed a clear assessment that the SP was having a stroke and recommendation for treatment with IV-tPA (94\% and 88\%, respectively). In addition, the SP noted that the majority of residents $(88 \%)$ were able to maintain composure and respond appropriately to concerns about the recommendation for IV-tPA. However, no residents were able to clearly explain the effect that IV-tPA would have on 3-month disability; in 13\% of encounters, the SP felt it was implied that treatment with IV-tPA was optimal but he was left guessing as to the magnitude of its effect and in $87 \%$ of encounters, the SP did not understand the benefit of IV-tPA on outcome at 3 months. The SP also noted that only a paucity of residents (18\%) clearly explained the risk of asymptomatic and symptomatic hemorrhage with IV-tPA and mentioned specific data while the majority of residents (77\%) implied IVtPA had some risks, but did not detail them. As a result, the SP only felt like he had a full understanding of the risks and benefits of treatment with IV-tPA in $29 \%$ of the resident encounters; in $65 \%$, he understood some, but not all, of the risks and benefits; and in 6\%, he had no understanding of the risks and benefits of IV-tPA.

\section{Discussion}

With the use of standardized patients, simulation can faithfully recreate clinical scenarios for training purposes without exposing patients to harm during the learning process. ${ }^{5}$ Simulation also provides the opportunity for trainee assessment based on direct observation and feedback on resident competency at communicating during a routine clinical scenario. The potential role for simulation in neurology trainee education about core activities, such as IV-tPA consent, is particularly relevant at present, given that neurology training is moving towards a model of Entrusted Professional Activities.?

Until now, residency didactic and simulation programs for acute stroke management have focused on the mechanics of running a stroke code, but have neglected the IV-tPA consent process. ${ }^{8-10}$ Our experience demonstrates that residents are 
skilled at communicating their assessment that a patient is having a stroke and their recommendation for IV-tPA, but they need practice and feedback about explaining the long-term benefits and the potential adverse effects of thrombolysis. It is clear that our IV-tPA consent case was warranted. However, our results are based on only a small number of residents from a single institution. Replicating this OSCE is feasible for programs with a simulation center, and it is worth noting that it is not time-intensive (we evaluated 17/18 first-year neurology residents in a 4-station OSCE in 2 afternoon sessions).

Providing residents with standardized supervised simulationbased education about IV-tPA consent can prepare them for real-life situations that they will encounter frequently throughout their training. Receiving feedback on the IV-tPA consent process early in residency may enhance resident confidence and ability to communicate the risks/benefits of IV-tPA both thoroughly and efficiently and improve patient outcomes. While we received positive feedback from the residents about this simulation, the effectiveness remains to be seen. Future work will determine whether participation will translate into competency obtaining IV-tPA consent, and whether it will improve rate of consent and affect door-toneedle time, thereby optimizing clinical outcomes.

Standardized simulation-based IV-tPA consent training with direct observation and real-time feedback is a feasible educational initiative for neurology residents. Additional experience will clarify if the simulation is effective at improving IV-tPA consent competency.

\section{Author contributions}

Dr. Rostanski: study concept and design, drafting of the manuscript, analysis and interpretation. Dr. Kurzweil: study concept and design. Dr. Zabar: study concept and design, critical revision of the manuscript for important intellectual content. Dr. Balcer: study concept and design. Dr. Ishida: critical revision of the manuscript for important intellectual content. Dr. Galetta: critical revision of the manuscript for important intellectual content. Dr. Lewis: study concept and design, critical revision of the manuscript for important intellectual content.

\section{Study funding}

No targeted funding reported.

\section{Disclosure}

The authors report no disclosures relevant to the manuscript. Go to Neurology.org/N for full disclosures.

\section{References}

1. American Academy of Neurology Policy on Consent Issues for the Administration of IV TPA. buyabrain.net/globals/axon/assets/8847.pdf. Accessed July 18, 2018.

2. Mendelson SJ, Courtney DM, Gordon EJ, Thomas LF, Holl JL, Prabhakaran S. National practice patterns of obtaining informed consent for stroke thrombolysis. Stroke 2018;49:765-767.

3. Mendelson SJ, Aggarwal NT, Richards C, O’Neill K, Holl JL, Prabhakaran S. Racial disparities in refusal of stroke thrombolysis in Chicago. Neurology 2018;90: e359-e364.

4. Anandaiah A, Rock L. Twelve tips for teaching the informed consent conversation. Med Teach 2018;1-6.

5. Hocker S, Wijdicks EF, Feske SK, Drislane FW. Use of simulation in acute neurology training: point and counterpoint. Ann Neurol 2015;78:337-342.

6. Gadhia J, Starkman S, Ovbiagele B, Ali L, Liebeskind D, Saver JL. Assessment and improvement of figures to visually convey benefit and risk of stroke thrombolysis. Stroke 2010;41:300-306.

7. Horak H, Englander R, Barratt D, Kraakevik J, Soni M, Tiryaki E; UES subcommittee of the AAN. Entrustable professional activities: a useful concept for neurology education. Neurology 2018;90:326-332.

8. Mehta T, Strauss S, Beland D, Fortunato G, Staff I, Lee N. Stroke simulation improves acute stroke management: a systems-based practice experience. J Grad Med Educ 2018;10:57-62.

9. Ruff IM, Liberman AL, Caprio FZ, et al. A resident boot camp for reducing door-toneedle times at academic medical centers. Neurol Clin Pract 2017;7:237-245.

10. Khan M, Baird GL, Price T, et al. Stroke code simulation benefits advanced practice providers similar to neurology residents. Neurol Clin Pract 2018;8:116-119. 


\section{Neurology}

\section{Education Research: Simulation training for neurology residents on acquiring tPA consent: An educational initiative}

Sara K. Rostanski, Arielle M. Kurzweil, Sondra Zabar, et al.

Neurology 2018;91;e2276-e2279

DOI 10.1212/WNL.0000000000006651

\section{This information is current as of December 10, 2018}

\section{Updated Information \&} Services

References

Citations

Subspecialty Collections

Permissions \& Licensing

Reprints including high resolution figures, can be found at: http://n.neurology.org/content/91/24/e2276.full

This article cites 8 articles, 6 of which you can access for free at: http://n.neurology.org/content/91/24/e2276.full\#ref-list-1

This article has been cited by 2 HighWire-hosted articles: http://n.neurology.org/content/91/24/e2276.full\#\#otherarticles

This article, along with others on similar topics, appears in the following collection(s):

All Cerebrovascular disease/Stroke

http://n.neurology.org/cgi/collection/all_cerebrovascular_disease_strok e

Methods of education

http://n.neurology.org/cgi/collection/methods_of_education Other Education

http://n.neurology.org/cgi/collection/other_education

Information about reproducing this article in parts (figures,tables) or in its entirety can be found online at:

http://www.neurology.org/about/about_the_journal\#permissions

Information about ordering reprints can be found online:

http://n.neurology.org/subscribers/advertise

Neurology ${ }^{\circledR}$ is the official journal of the American Academy of Neurology. Published continuously since 1951 , it is now a weekly with 48 issues per year. Copyright @ 2018 American Academy of Neurology. All rights reserved. Print ISSN: 0028-3878. Online ISSN: 1526-632X.

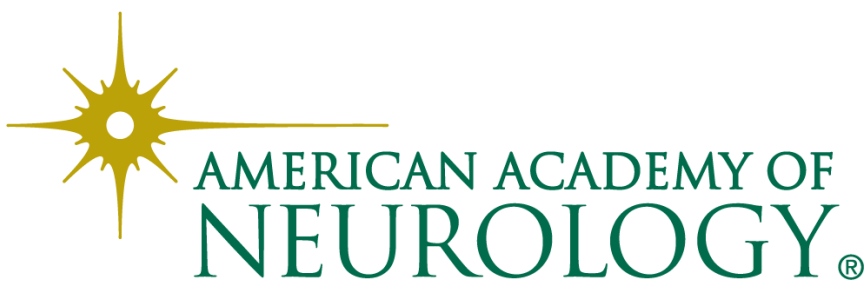

